\title{
Pseudocercospora leaf and fruit spot disease of citrus: Achievements and challenges in the citrus industry: A review
}

\author{
Mohammed Yesuf \\ Ethiopian Institute of Agricultural Research (EIAR), Nazareth, Ethiopia; mohanarc@yahoo.com
}

Received 30 May 2013; revised 15 June 2013; accepted 17 June 2013

Copyright (C) 2013 Mohammed Yesuf. This is an open access article distributed under the Creative Commons Attribution License, which permits unrestricted use, distribution, and reproduction in any medium, provided the original work is properly cited.

\begin{abstract}
Citruses are the worlds' second fruit crops by volume next to banana. It is one of the most important commodity in tropical Africa as source of foreign currency, raw material for agro-industries and source of employment. The production and productivity of citrus in tropical Africa including Ethiopia are critically threatened by a number of diseases. Among others, pseudocercospora leaf and fruit spot of citrus caused by a fungus Pseudocercospora angolensis is the most destructive disease of citrus. Literature reviews have been made by searching the available information on leaf and fruit spot of citrus. Journal articles, research papers, workshop proceedings, Thesis research, manuals, and quarantine regulations were among the information sources of the review. The disease is widespread in 22 African countries including Ethiopia with a single report around Yemen in the Arabian Peninsula. Scattered research efforts have been made by different researchers in Africa mainly dealing with its geographic distribution, biology, and management practices. Fungicides, plant extracts/essential oils, and host resistance are among the research efforts made for the control of $P$. angolensis. Even though the disease is not yet reported to the rest of the world, it becomes a serious concern as an important quarantine pest thereby critically affecting the world trade and germplasm exchange of the citrus industry. Therefore, the purpose of this paper is to compile the scattered information on various aspects of leaf and fruit spot of citrus mainly to avail the information for researchers, development workers and policy people. Moreover, this review will suggest future
\end{abstract}

research and development direction towards better understanding and sustainable management practices of the disease.

Keywords: Leaf and Fruit Spot; P. Angolensis; Citrus; Tropical Africa

\section{INTRODUCTION}

Citrus is the most important tropical fruit widely grown all over the world. It is the second largest by production volume next to banana [1]. Citrus has got multiple advantages including food source, raw material for agro-industries, income generation and source of employment especially for the rural poor. The Government policy on the promotion of citrus production in Africa is quite encouraging as the sector has got attractive and multiple social and economic advantage. In tropical Africa, particularly Sub-Saharan Africa production of citrus is seriously hampered by a fugal disease caused by Pseudocercospora angolensis [2]. The yield reduction due to this disease can reach 50\% - 100\% when climatic conditions are favorable to the disease development, and a timely effective control measures are not taken (Seif, 1994).

Pseudocercospora leaf and fruit spot of citrus is widespread in 22 different African countries and Yemen around the Middle East [3-5]. The disease is not yet reported in the Northern part of Africa and South Africa, where the bulk of citrus production is concentrated [6]. Even though, the disease is not yet reported in the rest of the world, there is a fear that the disease may appear by air borne conidia from the neibouring $P$. angolensis affected countries, and adversely affect the international trade on citrus.

A number of research efforts have been made in different parts of Africa where the disease is widespread. Some of the research efforts include mapping the geo- 
graphic distribution [5] inoculation techniques, disease management practices with a focus on host-plant resistance, botanical control, sanitation measures and fungicide application [3,7]. However, the limited available information on the research output of this important disease is too scattered. Moreover, despite the importance of the disease on citrus industry, there were no collaborative research and development efforts both in the region and under the international arena.

Therefore, the aim of this review is to compile the available and scattered research and development efforts, share the limited experience on this economically important disease of citrus to the rest of the world where it is not yet reported and also suggest future research and development directions towards better understanding on the distribution, biology and management options of Pseudocercospora leaf and fruit spot disease of citrus.

\section{HISTORY AND OCCURRENCES OF LEAF AND FRUIT SPOT OF CITRUS IN AFRICA}

The first occurrence of Phaeoramularia leaf and fruit spot disease of citrus was in Angola and Mozambique in 1952 [8]. Latter the disease widespread to other parts of West Africa, Central Africa, East Africa and the Middle East [7,9-11]. The very recent occurrence of $P$. angolensis is in Sierra Leone in 2010 [12]. The characteristic symptoms of the disease in Ethiopia was recorded around Aletawondo and Dale areas of Southern Ethiopia in 1988 [13]. The causal agent of the disease was positively identified in Ethiopia in 1990 [4]. Currently, the disease widespread to south, south-west, and north-west of Ethiopia causing heavy crop damage some times up to total crop loss [5]. The chronology of occurrences of leaf and fruit spot disease in different African countries is presented in Table 1.

\section{SYMPTOMS AND/NATURE OF DAMAGE}

The disease attack leaves fruits and twigs of all citrus species at various levels of severity. Grape fruit, sweet orange and mandarin are known as highly susceptible where as lemon and lime are least susceptible. Typical symptoms of the disease include leaf spots surrounded with yellow halo, and fruit spots/lesions that makes the appearance of the fruits un attractive and also very hard (Figure 1). The devastating nature of the disease is heavy defoliation of leaves and fruits. Fruits can be attacked at all growing stages, whereas leaves are less affected as they got older.

\section{BIOLOGYIEPIDEMIOLOGY}

Development and spread of $P$. angolensis is favored in
Table 1. Chronology of occurrences of Pseudocercospora leaf and fruit spot of citrus in different countries.

\begin{tabular}{|c|c|c|c|}
\hline No. & Country & Year & References \\
\hline 1 & Angola & 1952 & {$[8]$} \\
\hline 2 & Mozambique & 1952 & [8] \\
\hline 3 & Zaire & 1966 & [14] \\
\hline 4 & Central African Republic & 1968 & [14] \\
\hline 5 & Cameroon & 1969 & [8] \\
\hline 6 & Gabon & 1971 & [8] \\
\hline 7 & Congo & 1971 & [14] \\
\hline 8 & Cotedivoire & 1972 & [14] \\
\hline 9 & Togo & 1972 & [14] \\
\hline 10 & Zambia & 1973 & [11] \\
\hline 11 & Nigeria & 1978 & {$[27]$} \\
\hline 12 & Burundi & 1980 & - \\
\hline 13 & Zimbabwe & 1982 & [11] \\
\hline 14 & Uganda & 1983 & [11] \\
\hline 15 & Kenya & 1984 & [6] \\
\hline 16 & Comoros & 1985 & [11] \\
\hline 17 & Yemen & 1986 & [11] \\
\hline 18 & Tanzania & 1990 & - \\
\hline 19 & Ethiopia & 1990 & {$[4,30]$} \\
\hline 20 & Republic of Guinea & - & {$[10]$} \\
\hline 21 & Ghana & - & [29] \\
\hline 22 & Rwanda & - & [10] \\
\hline 23 & Sierra Leone & 2010 & [12] \\
\hline
\end{tabular}

Source: $[9,10]$.

areas with high rain fall and humidity above $75 \%$. The disease restricted to species of Citrus, including grapefruits (C. paradisi), limes (C. aurantifolia), mandarins (C. reticulata), oranges (C. sinensis), rangpur limes (C. limonia), rough lemons (C. jambhiri) and sour oranges $(C$. aurantium). Under natural conditions, spores of $P$. angolensis probably spread by air-borne conidia [9]. Leaves of planting material or fruits seem the most likely pathways for the transfer of the pathogen. Citrus fruits can be attacked at all growing stages, whereas leaves are less affected as they got older. There is no report yet regarding its host range other than citrus species.

\section{GEOGRAPHIC DISTRIBUTION}

The disease is widely distributed in west central and east African countries. A single report also exists in Yemen (Figure 2). No report of leaf and fruit spot of citrus to the rest of the world. In many of the African countries $P$. angolensis is widely distributed in areas with high rain fall and relative humidity. It is assumed that the disease could be a potential threat in other new areas with similar agro-ecology. 


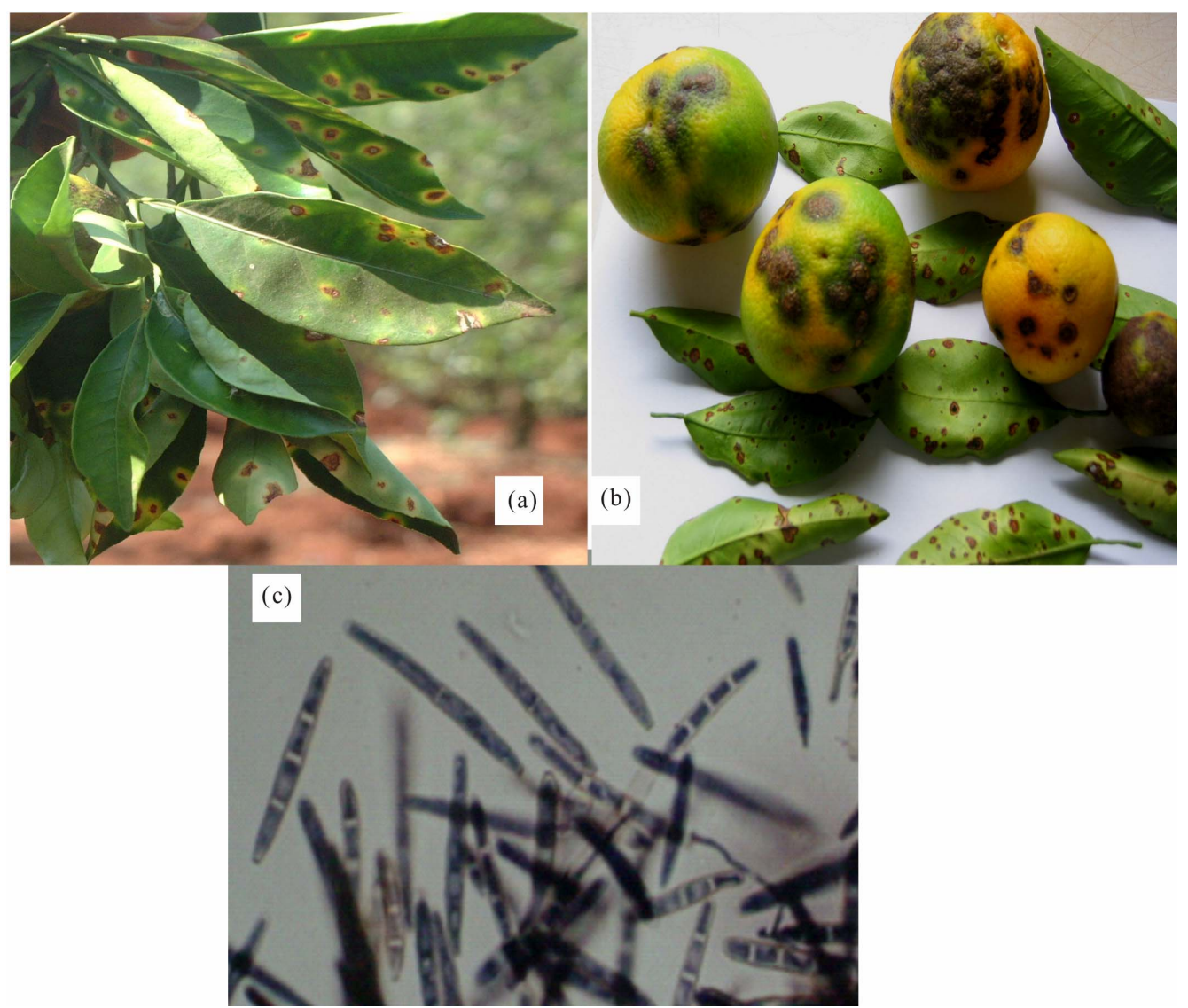

Figure 1. Characteristic symptoms of Pseudocercospora leaf and fruit spot disease on sweet orange ((a) Upper side of leaves; (b) Fruits and back side of the leaves; (c) Conidia of P. angolensis).

\section{ECONOMIC SIGNIFICANCE}

Many of the African countries gave high priority to citrus production mainly due to its economic value as an export commodity, raw material for local industries, and also its viable employment opportunity for the local people. Moreover, due to its perennial nature citrus plays a vital role on environmental protection. However, yield losses due to leaf and fruit spot of citrus ranges from $50 \%-100 \%$ in many citrus producing countries of tropical Africa [14-16]. In most Sub-Saharan African countries the supply of citrus fruits especially sweet orange is far below the demand mainly due to a significant yield loss incurred due to leaf and fruit spot disease.

Due to its devastating nature and geographic distribution, leaf and fruit spot of citrus is considered as a quarantine pest for Europe. This will critically affect the market linkage of the citrus industry and also the germplasm exchange between countries. Moreover, this economically important disease can cause a potential threat to the rest of the world, especially to citrus growing areas of the tropical climate.

\section{CONTROL MEASURES}

Efforts have been made to manage leaf and fruit spot disease of citrus in different parts of Africa. However, complete disease control was not achieved in any of the countries affected by P. angolensis. Among the recommended control methods, sanitation measures, botanical control, host plant resistance and chemical control are reported by different researchers [5,7,17-22].

\section{CULTURAL PRACTICE}

Few attempts were made to control the disease using cultural practices such as sanitation measures and use of wind breaks. Removal of infected and defoliated leaves, and dropped fruits reduced the build-up of $P$. angolensis (unpublished data). Use of wind breaks also played a positive role on the reduction of wind borne inoculum of P. angolensis.

\section{PLANT EXTRACTS/BOTANICALS}

Due to environmental and food safety concerns, it is mandatory to investigate other disease management practices against leaf and fruit spot disease of citrus. Accordingly, extracts of some plant products have shown a promise as potential management options for leaf and fruit spot of citrus. Essential oils extracted from leaves of three 


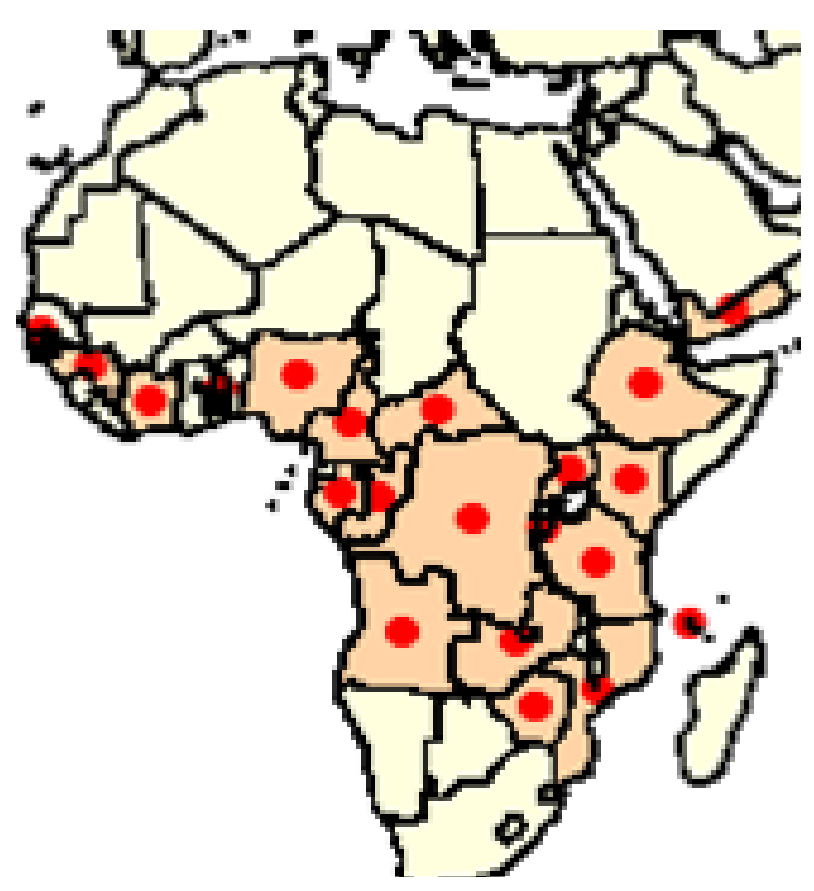

Figure 2. Geographic distribution of leaf and fruit spot of citrus in Africa [31].

citrus varieties (Bears, Mexican and Sans) are showed potential antifungal activity for the control of leaf and fruit spot of citrus [22,23]. The mycelium growth of $P$. angolensis was completely inhibited at 6000 and 6500 ppm using extracts of Eucalyptus saligna and Eucalyptus camaldulensis respectively [24].

\section{HOST PLANT RESISTANCE}

Susceptibility varied among citrus species and cultivars against leaf and fruit spot disease. In similar cultivars leaves and fruits are not equally susceptible [25]. Marsh seedless grapefruit, pineapple orange, Valencia late, Washington Navel, Cleopatra tangerine, Kara tangerine, Mineola tangelo, Villa Franca lemon, and Lisbon lemon were very susceptible. Eureka lemon, Satsuma tangerine, and Troyer citrange were less susceptible, while Tahiti lime was least susceptible under Kenyan condition [26]. These findings were in confirmation with other research findings in West Africa [10,27]. Sweet orange cultivars Jaffa and Campbell valencia were classified as moderately resistant, where as Washington naval, Pineapple and Hamline were classified as moderately susceptible to the disease [19].

\section{CHEMICAL CONTROL}

A number of fungicides have been recommended against leaf and fruit spot of citrus in different parts of Africa. Benomyl, Chlorothalonil and Copper hydroxide were recommended as foliar spray in Ethiopia and Kenya $[5,7,16,18,19]$.

\section{DISCUSSION AND CONCLUSION}

Many of the agricultural development policies in SubSaharan African countries gave high priority for the promotion of fruit production in general, and the citrus industry in particular. Both the regional and global demand for citrus is also still increasing at its alarming rate due to the economic and social importance of citruses. This is an opportunity to the citrus industry to be easily linked to the regional and international markets. But there are also challenges in relation to consumer's preference for health/ quality fruits. The other challenge is the concern of quarantine pest such as $P$. angolensis of citrus, which is registered as a major quarantine pest for Europe and America and is a big challenge of the sub-sector in many citrus growing tropical African countries. The available information indicates that leaf and fruit spot of citrus is remaining a critical threat of citrus production in Sub-Saharan Africa. Germplasm exchange and the citrus trade with other regional and International institutions/countries are also hampered mainly due to its quarantine importance in many of the citrus growing countries. It has been reported that as the disease causes extensive foliar and fruit damage and seems to have potential to become a significant problem in Florida if introduced as the pathogen prefers warm and humid climates [28].

Despite the economic importance of Pseudocercospora leaf and fruit spot disease in the citrus industry, detailed information on its characterization, biology, and epidemiology is still lacking. The research outputs on disease management practices need to be packaged for further technology scaling-up so as to develop a sustainable and safe disease management options. Moreover, a multi-stakeholder approach for research and development endeavors is vital to better understand the disease biology, and device sustainable disease management practices thereby to reduce the yield loss and improve the quality of citrus fruits. This major threat of the citrus industry warrants experience sharing, collaboration on research and development efforts both at national, regional and International level.

\section{REFERENCES}

[1] FAO (2006) Statistical data base. Citrus production.

[2] Seif A.A. and Whittle A.M. (1984) Diseases of citrus in Kenya. FAO Plant Protection Bulletin, 32, 122-127.

[3] Seif, A.A. and Hillocks, R.J. (1993) Phaeoramularia fruit and leaf spot of citrus with special reference to Kenya. International Journal of Pest Management, 39, 44-50. doi:10.1080/09670879309371757

[4] Eshetu, D. (1997) Leaf and fruit spot: A new disease of citrus in Ethiopia. Proceedings of 7th Annual Conference of Crop Science Society, Addis Abeba, 27-28 April 1997, 215-221. 
[5] Mohammed, Y. (2007) Distribution and management of Phaeoramularia leaf and fruit spot disease of citrus in Ethiopia. Fruits, 62, 99-106. doi:10.1051/fruits:2007003

[6] Seif, A.A. and Whittle, A.M. (1984) Cercospora fruit and leaf spot of citrus. Annual Report of the National Horticultural Research Centre Thika, Kenya.

[7] Eshetu, D. (1999) Occurrence, prevalence and control method of Phaeoramularia leaf and fruit spot disease of citrus in Ethiopia. Fruits, 54, 225-232.

[8] De Carvalho, T. and Mendes, O. (1952) Uma cercosporiose em Citrinos. Motambique, 72, 1-8.

[9] Seif, A.A. and Hillocks, R.J. (1998) Some factors affecting infection of citrus by Phaeoramularia angolensis. Journal of Phytopathology, 146, 385-391.

[10] Kuate, J. (1998) Citrus fruit and leaf spot disease caused by Phaeoramularia angolensis. Cahiers Agricultures, 7, 121-129.

[11] Kirk, P.M. (1986) Phaeoramularia angolensis. CMI Descriptions of Pathogenic Fungi and Bacteria, Mycopathologia, 94, 177-178.

[12] Harling, R., Shamie, I.M.O., Sesay, S.S., Kamara, A.B., Reeder, R., Boa, E. and Kelly, P. (2010) First report of Pseudocercospora angolensis causing leaf and fruit spot of citrus in Sierra Leone. New Disease Reports, 22.

[13] Yimenu, J. (1993) Preliminary survey report on leaf spot disease of citrus in Sidamo. Field Trip Report, Coffee Development Authority, Addis Abeba, Ethiopia.

[14] Brun, J. (1972) La cercosporiose des agrumes provoquée par Cercospora angolensis. Fruits, 27, 539-541.

[15] Kuate, J., Bella, M, Foure, E. and Rey, J.Y. (1994) Symptoms de la cercosporios des agrumes due a Phaeoramularia angolensis. Fruit, 49, 31-36.

[16] Seif, A.A. (1994) Studies on Phaeoramularia fruit and leaf spot disease of citrus in Kenya. Ph.D. Thesis, University of Reading, Reading.

[17] Manga, M., Dubois, C., Kuaté, J., Mimbimi, N.M. and Rey, J.Y. (1999) Susceptibility to Phaeoramularia angolensis of some citrus varieties grown in the Cameroon rain forests. Fruits, 54, 167-176.

[18] Seif, A.A. and Hillocks, R.J. (1997) Chemical control of Phaeoramularia fruit and leaf spot of citrus in Kenya. Crop Protection, 16, 141-145.

[19] Kassahun, T., Temam, H. and Sakuja, P.K. (2006) Management of fruit and leaf spot disease in Ethiopia. Agricultura Tropica et Subtropica, 39, 242-245. doi:10.1016/S0261-2194(96)00086-5

[20] Ducelier, D. (2006) Effect of essential oils from citrus varieties on in vitro growth and sporulation of Phaeoramularia angolensis causing citrus leaf and fruit spot dis- ease. European Journal of Plant Pathology, 114, 151161. doi:10.1007/s10658-005-2928-7

[21] Tchinda, E.S., Jazet, P.M.D., Tatsadjieu, L.N., Ndongson, B.D., Amvam, P.H.Z. and Menut C. (1999) Antifungal activity of the essential oil of Cymbopogon citratus (Poaceae) against Phaeoramularia. Journal of Essential Oil Bearing Plants, 12, 218-224. doi:10.1080/0972060X.2009.10643714

[22] Kuate, J., Foko, J., Ndindeng, S.A., Dongmo, P.M.Z., Foure, E., Damesse, F., Manga, B. and Ducelier, D. (2006) Effect of essential oils from citrus varieties on in vitro growth and sporulation of Phaeoramularia angolensis causing citrus leaf and fruit spot disease. European Journal of Plant Pathology, 114, 151-161. doi:10.1007/s10658-005-2928-7

[23] Dongmo, P.M., Tastadjieu, N.L., Tchinda, S.E., Kuate, J., Zollo, P.A. and Menut, C. (2008) Antiradical potential and antifungal activities of essential oils of the leaves of citrus latifolia against Phaeoramularia angolensis. African Journal of Biotechnology, 22, 4045-4050.

[24] Dongmo, P.M.J., Ngoune, L.T., Dongmo, B.N., Kuate, J., Zollo, P.H.A. and Menut C. (2008) Antifungal potential of Eucalyptus saligna and Eucalyptus camaldulensis essential oils from Cameroon against Phaeoramularia angolensis. European Journal of Scientific Research, 24, 348-357.

[25] Kuate, J., Foure, E., Foko, J., Tchio, F. and Ducelier, D. (1997) Experimental inoculation of Phaeoramularia angolensis in young nursery citrus plantlets. Fruits, 52, 149157.

[26] Seif, A.A. (1999) Reaction of some citrus cultivars to Phaeoramularia fruit and leaf spot in Kenya. Fruits, 54, 323-329.

[27] Emechebe, A.M. (1981) Brown spot of citrus caused by Phaeoisariopsis sp. Annals of Applied Biology, 97, 257262. doi:10.1111/j.1744-7348.1981.tb05110.x

[28] Chung, K.R. and Timmer, L.W. (2007) Citrus diseases exotic to Florida, Phaeoramularia fruit and leaf spot (PFLS). Fact Sheet, Plant Pathology Department, University of Florida, 234.

[29] Megan, D. and Timmer, I.W. (2009) Citrus production and diseases in Ghana. Citrus Industry.

[30] Mohammed, Y. (2001) Phaeoramularia leaf and fruit spot of citrus, a major threat to citrus production in tropical Africa. Proceedings of Hortic Workshop on Sustainable Horticultural Production in the Tropics, Jomo Kenyata University, Nairobi, 3-6 October 2001, 18-25.

[31] EPPO (2006) Distribution maps of quarantine pests for Europe. Phaeoramularia angolensis. 